\title{
Volunteering in the Heritage Sector: Opportunities and Trends
}

\author{
Mihaela PĂCEȘILÄ $\breve{A}^{1}$
}

\begin{abstract}
The purpose of this paper is to get a deeper understanding of the role of heritage volunteering in young people's personal and professional development. The empirical research is based on a survey of a sample of 50 volunteers within the National Museum of Romania History from Bucharest. The study indicates that heritage volunteering is important for both individuals and community. Furthermore, the results of the research showed similarities with certain authors' statements mentioned in section Theoretical background. Overall, this research demonstrates the value of heritage volunteering in a society where professional experience and networking are extremely important in finding a job for young people.
\end{abstract}

KEYWORDS: benefits of volunteering in museums, heritage volunteering, professional development.

JEL CLASSIFICATION: $B 10, Z 10, Z 19$

\section{INTRODUCTION}

The concept of volunteering encompasses a myriad of meanings, its definitions being largely influenced by the values and beliefs of each state in whose territory volunteer activities take place. Over time, countless authors have tried to define the volunteer movement; some focused on idealistic notions, others conceptualized more than they should, and others failed to cover all aspects involved in volunteering.

In a world characterized by an expanding globalization process, with an emphasis on independence and complexity, volunteering becomes an essential component of human society (Păceșilă, 2017), because it implements humanity's greatest desires: equality, justice, peace and safety for all social actors. Volunteering allows strengthening and supporting the society's values through activities undertaken for the others (Profiroiu and Păceșilă, 2017). Moreover, the volunteering offers people the opportunity to learn and develop continuously, exercising their rights and obligations as members of civil society (International Association for Volunteer Effort, 2001) Volunteering is the activity of any individual who accepts to work without receiving a reward (Handy et al., 2000; Haski-Leventhal et al., 2009) or proof of the work undertaken (Whittaker et. al. 2015). In the same spirit, Rodriguez and Gutierrez (2010) consider that volunteering is the activity of a person who chooses to help others, usually unknown individuals, without receiving economic rewards.

According to Balogh and Balogh (2013), volunteering refers to a series of common traits, whatever the nature of the charitable activity: voluntary, flexible and non-compulsory activity, benefiting activity on the community. Smith (1999) mentions that definitions of volunteering focus on three key aspects: gift of time, free choice and lack of remuneration. Volunteering is an important object of study for a wide range of disciplines such as: economics, sociology,

1 Department of Administration and Public Management, Bucharest University of Economic Studies, mihaela.pacesila@man.ase.ro 
psychology, management etc. These disciplines assign different meanings and functions to volunteering. In an economic paradigm, volunteering is mainly understood as ,unpaid work" whose economic value can be calculated because volunteers carry out their activity as an investment in their human capital (Hustinx et al., 2010). On the other hand, sociologists and scientists consider volunteering as an expression of the fundamental principles of society, such as solidarity, social cohesion and democracy. The psychological study of volunteering refers to identifying the personality traits such as orientation to social values, empathy, effectiveness, self-esteem that distinguish volunteers from "non-volunteers" (Putnam, 2000; Wuthnow, 1998).

In Western Europe, volunteering is an opportunity to acquire new skills and carry out a useful work, especially in countries where unemployment and demographic aging are major issues. As regards politicians, they agree that volunteering could be "a possible bridge between citizen and state" (Smith 1996). In Eastern and Central Europe volunteering plays a significant role in strengthening democracy and in developing a new citizen society (Smith, 1999).

\section{THEORETICAL BACKGROUND}

Although volunteering in art and culture is relatively low, volunteers are an important component of the workforce within Western cultural institutions. Groninger (2011) points out that museum volunteering in Western countries is guided by four principles: knowledge of the subjects, community interest, reward system and code of ethics imposed by the profession of volunteer into museums.

Volunteers are considered the unpaid employees of the cultural institution (Edwards, 2005). In this regard, Lord and Lord (2009) identifies three different roles that volunteers could play in a museum: board members (volunteers who work on boards), volunteer manager (who coordinates the activity of other volunteers) and active volunteers (who undertake daily activities).

In literature there are several terms for museum volunteers such as "docent" or "apprenticeship system", used mainly in North America. More specifically, the concept "docent" refers to a person offering guided tours to the groups of visitors (Dake, 2014), while "the apprenticeship system" refers to all "full time" volunteers performing volunteer activities in the museum (Smith, 1999)

On the other hand, according to Hooper-Greenhill and Chadwick (1985) there are two main categories of museum volunteers: aspiring museums professional and individuals having a great deal of free time and skills/knowledge to offer. The aspiring museums professional is the person having high expectations both from the museum and from its own potential. He sees volunteering as an important means of entering the paid museum labor market and as a demonstration of commitment and experience (Holmes, 2005). The aspiring museums professionals could undertake volunteer activities in different stages: before, during and after graduating from university. The second category identified is the elderly (Holmes, 2002), who in western countries choose to do volunteer work in the museum.

In general, volunteers carrying out activities for the benefit of a cultural institution are highly trained individuals (Groniger, 2011; Holmes and Edwards, n.d.). Moreover, according to Ardelean (2009)_they are involved and passionate people because working in the cultural sector requires thorough training in order to fully control the museum's actions and mechanisms. Furthermore, Holmes (2003) points out that museum volunteers represent a specific type of clients engaged in certain activities that are part of the educational and promotion mission of the museum. 
Furthermore, according to Howlett et al. (2005), cultural institutions are interested in volunteering activities for various reasons: saving money allocated for salaries because they cannot have more employees (Catlin-Legutko and Klingler, 2012), "increasing diversity", involving volunteers brings a significant contribution to the added value of working in the museum, etc. According to the aforementioned author, the main barriers in museum volunteering are lack of a volunteer manager, lack of volunteer supervision time, different skills needed for volunteer management, lack of adequate volunteer training capacity, health and safety issues, concern for volunteers' commitment, lack of space, difficulty in finding and recruiting employees.

As regards volunteers' recruitment, most cultural organizations reported that they recruited volunteers through friends, websites, announcements in the press, volunteering fairs, local publications and leaflets, radio announcements, personal invitations (Howlett et al, 2005). Moreover, raising awareness of volunteer opportunities and interest for a particular organization or subject (the prestige of the museum), relations with other institutions, such as universities and high schools have made recruiting volunteers easier (Edwards, 2005).

Taking into account the volunteers' needs, Gaskin (2003) proposed a model in order to help organizations facilitate volunteer work. The model comprises four stages:

- The doubter: certain attitudes, characteristics or circumstances prevent him from being classified as a volunteer.

- The starter: decides to become involved in the cultural institution by applying for registration.

- The douer: took on the responsibility of volunteering and began to provide various services for the museum.

- The stayer: is a long-term volunteer.

Researchers (Kuyper et al., 1993; Debo, 2013) suggest that cultural organizations could help volunteers to integrate by training courses. In this regard, certain museums provide informal courses where volunteers are taught about their behavior during volunteering. However, the training used in NGOs could not be applied in the heritage sector because each field is characterized by a different functioning and organization of volunteering activities. Therefore, "learning in the workplace" as well as "need for knowledge for carrying out a task" are often the only solutions that should be taken into account when discussing about this type of volunteering (Groninger, 2011).

Training courses should include information about the mission, vision, values of the institution, institutional policies and procedures, the roles and responsibilities of volunteers, as well as the training itself (Debo, 2013). As reported by Hirzy (2007), the museums generally provide four types of training for volunteers: orientation to the museum and volunteer program, general training on volunteer responsibilities, specialized training for carrying out the tasks and opportunities for advanced training. The trainings within the museums should develop the volunteers as regards their skills, relationships, expectations and knowledge.

According to Kuyper et al. (1993) the training or lack of volunteers' training in museums shows the high or low level of professionalism. Moreover, the training shows the museum's investment in its volunteers, which should be considered important human resources. The training also contributes to building a relationship between volunteers and the institution (Grossman and Furano, 1999), but also between their work and the public service that the museum offers (Ohlandt, 2013).

The museums in developed countries have made significant efforts to formalize and systematize volunteering (Kotler and Kotler, 2001; Kelly et al., 2002; Edwards and Graham, 2006). In Debo's view (2013) formal procedures and practices, including volunteer agreements, training, supervision, and health/safety are components of the volunteering program. Volunteering policy clarifies the museum's policy of involving volunteers and their 
commitment to effective involvement (Hall, 1995). A volunteering policy is the cornerstone of good volunteer management (McLean, 1997) because it clarifies the position of volunteers within the organization (Smith, 1999). Millar (1991) strongly recommends the development of a volunteering policy and details the steps involved in its elaboration. Such a policy should reflect the museum's values, standards, and strategies (Debo, 2013). Furthermore, it should include the reasons for volunteering, involve all stakeholders within the institution and include a code of practice on the relationship between volunteer and organization, detailing each aspect of the management process.

The museums have a significant influence on volunteers, stronger than educational institutions because it stimulates both creativity and sensitivity, as well as mental faculties. Different studies (Mattingly, 1984; Holmes, 1999; Holmes, 2003; Edwards and Graham, 2006) have identified the benefits of volunteering in the heritage sector: learning about the visitors, using personal skills and learning new ones, making significant contribution to the community and meeting with individuals with similar interests for a field of activity. Moreover, compared to adults/elderly, young people tend to consider volunteering in the heritage sector as a way of learning new things, gaining new qualifications and skills in the field and acquiring important positions in cultural institutions. Furthermore, according to Dickens and Blomberg (1988) the person carrying out volunteering activities acquires social skills such as teamwork, seriousness, punctuality, communication, ability to keep calm in tense situations, ability to build relationships with others.

On the other hand, studies investigating the heritage volunteering identify the reasons why volunteers get involved in this sector: desire to acquire skills/experience (Holmes, 2003; Chen, 2014), to interact with people (visitors or other volunteers) having similar interests (Holmes and Edwards, n.d.); opportunity to meet new people and develop close friendships (Henderson, 1981; Chen, 2014); desire to share ideas, to gain experience of working in a museum (Smith, 1999).

Other motivations identified among museum volunteers refer to access and enthusiasm (Smith, 1999). Access represents a rational motivation, as individuals passionate about history and art have access to the collections within the museum. The enthusiasm for the collections or the museum itself is a significant motivation (Yang, 2015) because many volunteers love the location and the legacy of the museum. Those who volunteer their time within a museum feel enthusiasm for their work while the contact with visitors/collections represents important factors in maintaining it. In fact, the work performed by social individuals is always important because they have the opportunity to learn new things (Kelemen et al., 2017), while the richness of a museum of history or art does not consist only in the existing collections.

\section{RESEARCH METHODOLOGY}

This paper analyzes the opinions of volunteers of the National Museum of Romanian History regarding the role of heritage volunteering in their development in particular, as well as in young people's development in general.

The paper sets out three research hypotheses:

Hypothesis 1: Volunteers within the museum are strongly motivated enjoying nonfinancial benefits.

Hypothesis 2: At least 50\% of the respondents learned about the volunteering program from the university where they study.

Hypothesis 3: Volunteers' involvement in the activities of the museum is closely related to their professional development.

The quantitative method was used in order to obtain the information needed for the research. This method does not influence the subjects' responses, while the researcher is detached and 
does not induce certain responses. The instrument used is the questionnaire because it does not require high costs and the information can be obtained directly. Moreover, the questionnaire could be completed simultaneously by several people and allows hypotheses testing.

According to Chelcea (1975) the questionnaire represents a psychological and logical set of questions closely connected with the research hypotheses that generate a verbal or nonverbal behavior of the respondent which is subsequently recorded. In Babbie's view (1992) the questionnaire is a technique of collecting data through a set of questions regarding the agreement/disagreement of the respondents about certain statements. Moreover, Chelcea (2007) considers that the questionnaires consist of a smaller or greater number of questions addressed to potential respondents in a writable form. The questions refer to the respondents' interests, points of view, feelings and behaviors.

The sampling was used in order to ensure that the data is representative. According to Jupp (2010), sampling is a technique used to select a social category from a statistical population. There are two sampling methods: non-probability sampling and probability sampling (Babbie, 2013). This paper uses non-probability sampling, based on a specific purpose because there are no statistics of people volunteering in the museum under study.

The questionnaire was created on the Google Docs platform, and the answers were processed by using Microsoft Office Excel version 2010. The answers were collected from 50 young people who volunteered in the National Museum of Romanian History during 2014-2018. Data collection lasted two months, namely March and May 2018. The time taken to complete this questionnaire ranged from 5 to 10 minutes. The questionnaire is divided on two parts: questions regarding the respondents' profile and questions regarding the volunteering activities in the museum. The questionnaire consists of both closed-ended questions and open-ended questions.

\section{RESULTS AND DISCUSSIONS}

The questionnaire was applied to a reasonably representative sample of 50 people who volunteered in the past within the National Museum of Romanian History or who are currently involved in the volunteering activities of the institution.

The National Museum of Romanian History is one of the most important museums of history and archeology in Romania, both as regards its heritage and its surface. Moreover, the museum is an important actor on the contemporary scene of Romanian archeology (Popescu and Corboş, 2013). This museum was inaugurated on May 8, 1972 and it is located in the former Post Palace, a historical monument classified in category A (MNIR, 2017). The museum aims to exploit and manage the items of movable historical heritage preserved in its collections (MNIR, 2014).

\subsection{Respondents' profile}

According to figure 1 most of the people $(84 \%)$ who volunteer or have volunteered in the National Museum of Romanian History during 2014-2018 are aged between 19 and 25 years. Therefore, one can state that young people have a high interest in heritage volunteering. Respondents aged between 26 and 30 years represent $14 \%$ of the total number of volunteers. One possible explanation for this low percentage is that responsibilities multiply as young people get older while the time spent on volunteering decreases.

Figure 2 shows that there are no significant differences regarding the percentage of male and female respondents. However, the percentage of women volunteering within the Museum is 4\% higher than of men. This support the statement of certain authors (Wymer et al., 1996; Wymer, 2011) considering that women involve in volunteering more than do men. 


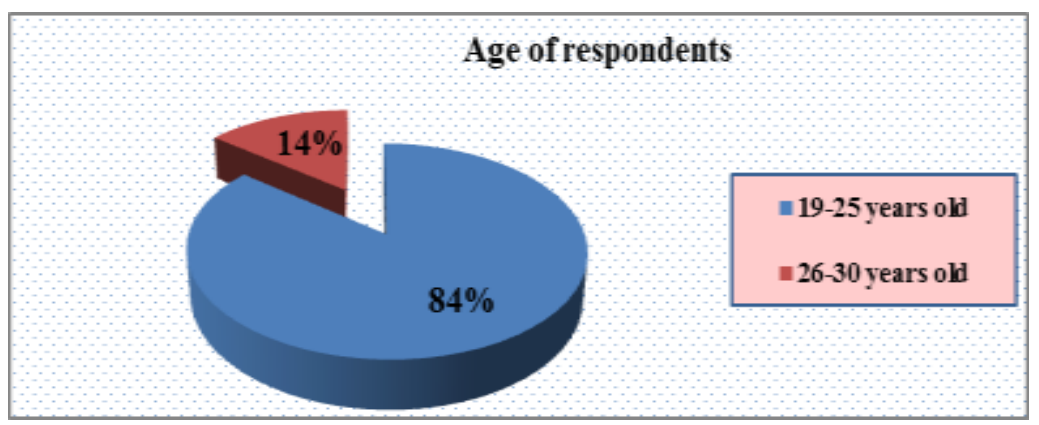

Figure 1. Age of respondents

Source: Author, 2020

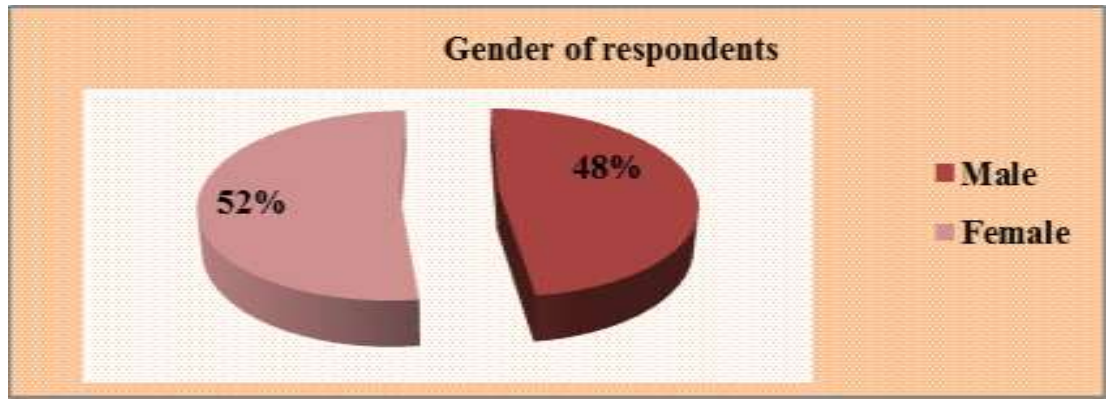

Figure 2. Gender of respondents

Source: Author, 2020

As regards volunteers' education (figure 3), most of them are either students or they have bachelor and master's degrees.

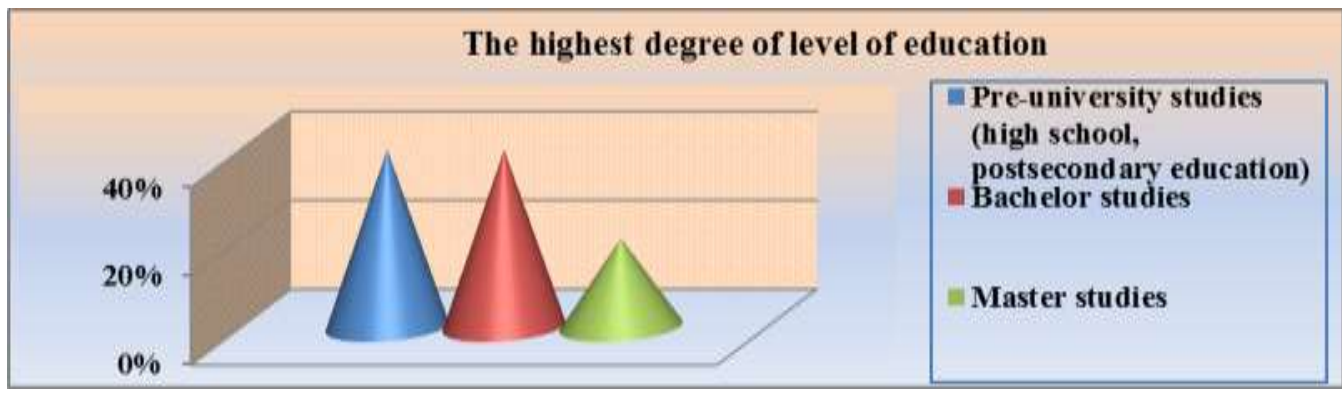

Figure 3. The highest degree of level of education

Source: Author, 2020

According to figure 4, the fields studied by the respondents are diverse because they are students/graduates of the different faculties in Bucharest. The percentage of volunteers from other faculties is smaller than the percentage of those from the Faculty of History. A possible explanation is that the National Museum of Romanian History is a partner institution of this faculty addressing topics of interest for the museum, such as museology and museography, archaeological heritage, protection of UNESCO heritage, etc. The involvement of students from other faculties in the volunteering activities of the museum shows their interest in culture.

As regards the respondents' status (figure 5), 60\% are students, $18 \%$ are employees and $22 \%$ are both students and employees. Therefore, more than half of volunteers are students because they probably have more time to get involved in the museum activities than those having a job. 


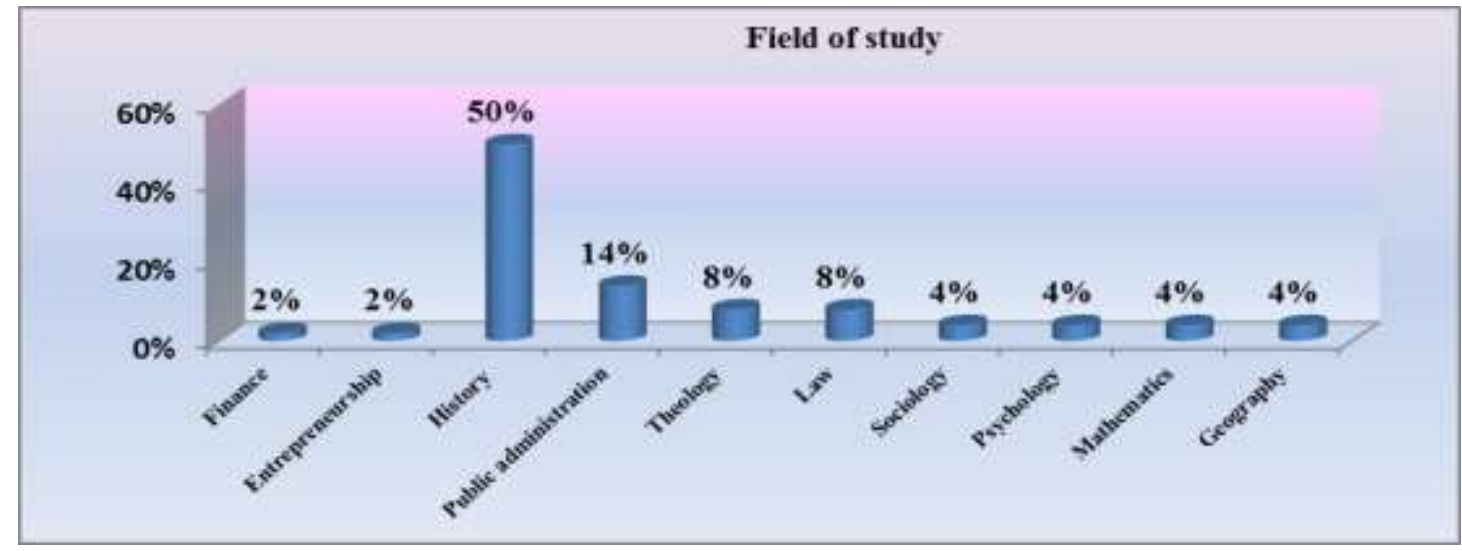

Figure 4. Field of study

Source: Author, 2020

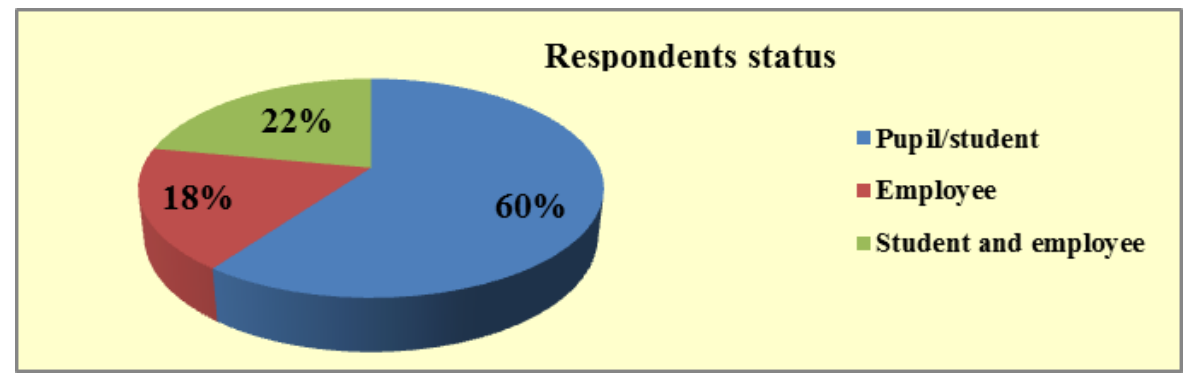

Figure 5. Respondents status

Source: Author, 2020

\subsection{Volunteering activity within the museum}

Approximately $60 \%$ of the respondents have been doing volunteer work in the museum for only a few months (Figure 6), while the remaining $40 \%$ have been involved for several years. Therefore, most of the museum's volunteers are in stages 3 (the douer) and 4 (the stayer) identified by Gaskin (2003).

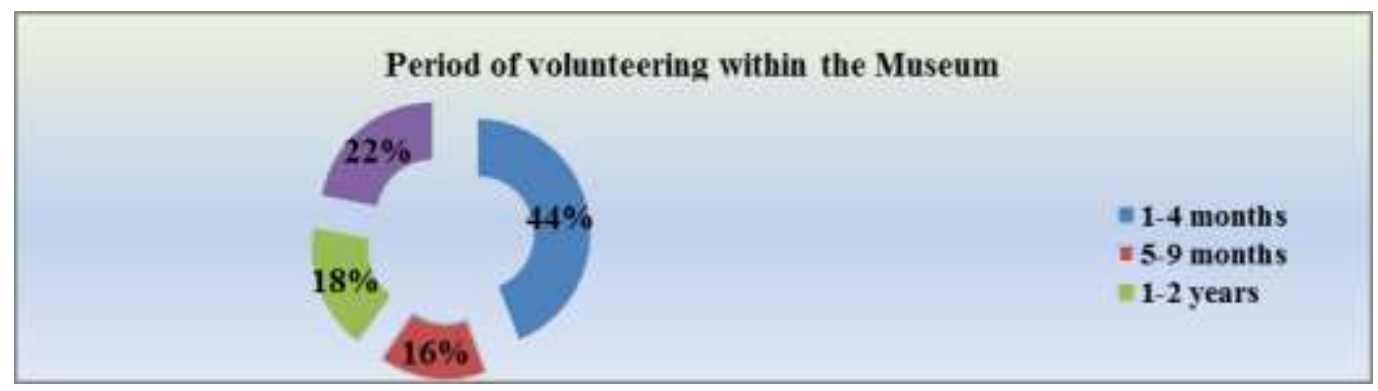

Figure 6. Period of volunteering within the Museum

Source: Author, 2020

Figure 7 shows the recruitment methods used by the institution, more precisely, the ways of promoting the museum's volunteering program. Therefore, approximately $50 \%$ of the volunteers are recruited through their faculties. The existing volunteers also play an important role, because the simple fact that their friends carry out interesting volunteering activities in a prestigious institution makes other social individuals to involve in the heritage sector. $20 \%$ of the respondents mentioned that they learned about volunteering from the museum's website or social networks. 


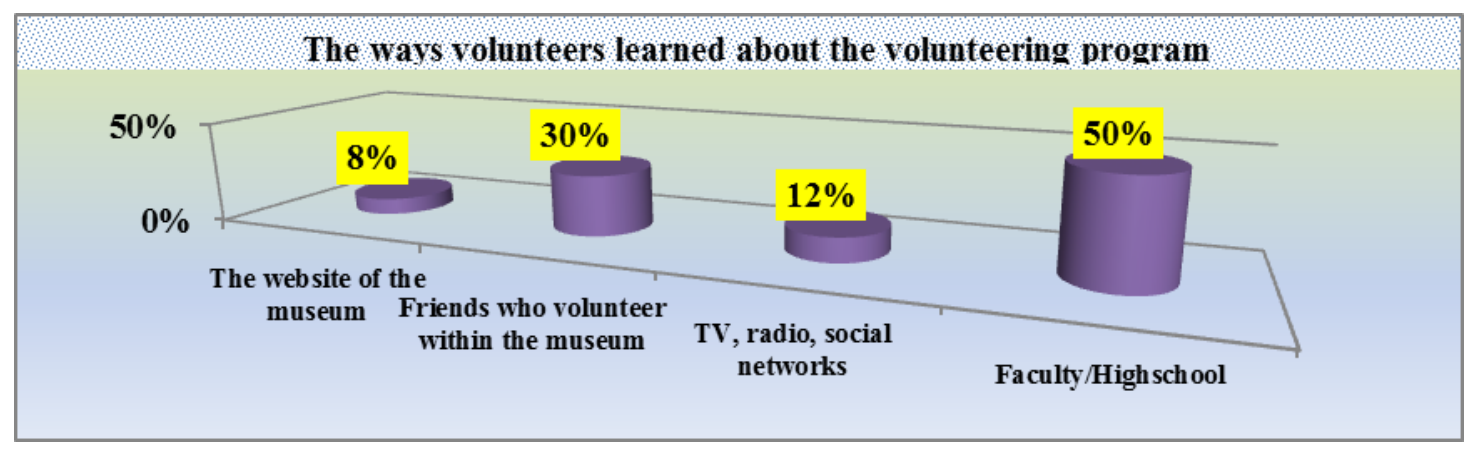

Figure 7. The ways volunteers learned about the volunteering program Source: Author, 2020

Approximately $52 \%$ of the respondent dedicate to heritage volunteering up to 3 hours per week, $42 \%$ between 4-10 hours while only 6\% more than 16 hours (Figure 8). Considering that many respondents are employees or both students and employees, with multiple responsibilities, it is explainable why most volunteers cannot get involved more than 10 hours per week in the volunteering work.

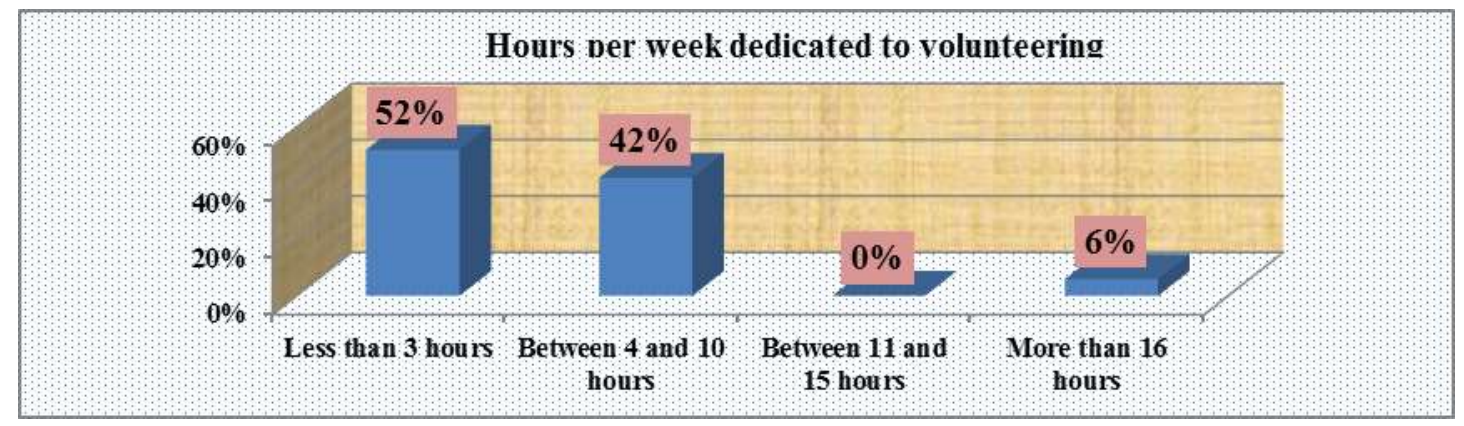

Figure 8. Hours per week dedicated to volunteering Source: Author, 2020

Figure 9 shows the main activities where volunteers are involved within the museum. The most popular activity is "Guided tours", followed by "Event supervisor such as Night of Museums, Doing School Differently Week", "and Facilitator in educational workshops", "Processing of ceramic material" and "Arranging temporary exhibitions".

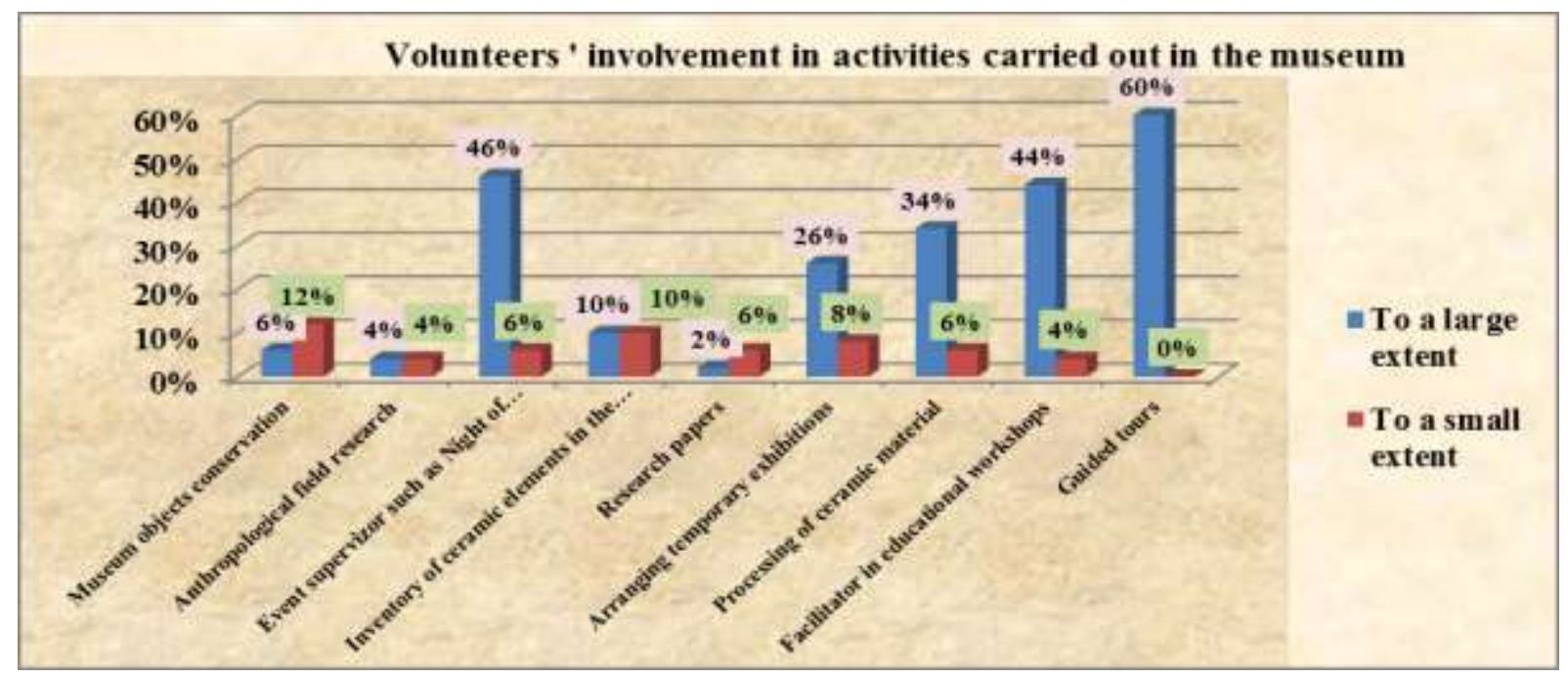

Figure 9. Volunteers' involvement in activities carried out in the museum Source: Author, 2020 
As regards "Research paper" and "Museum objects conservation", the number of the respondents is relatively small, because carrying out such activities requires specialized training. The other activities can be easily learned in the courses provided by the institution or even on the spot.

Figure 10 shows the reasons for volunteering within the museum. Social interaction, interest in history, gaining self-confidence, acquiring new skills and desire to help are some of the answer options that the respondents had to select to express their agreement or disagreement. The selections made by the respondents show that they feel an intrinsic and extrinsic, cognitive and affective motivation.

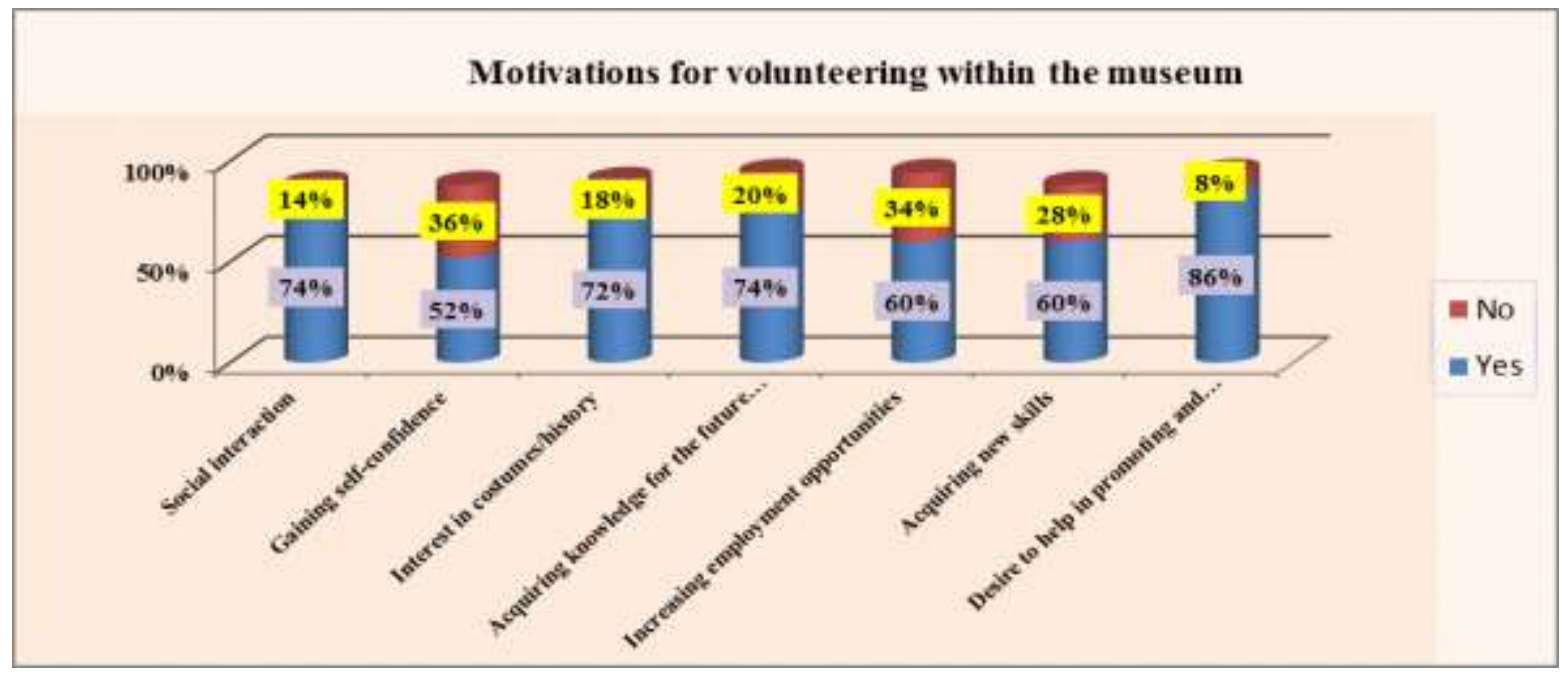

Figure 10. Motivations for volunteering within the museum

Source: Author, 2020

As regards the benefits of volunteering in a cultural institution (Figure 11), over half of the respondents answered that heritage volunteering helped them to develop personally, $24 \%$ mentioned that they spent their leisure time in a constructive way, for $10 \%$ of the respondents the volunteer work has improved their knowledge of history, while other $10 \%$ managed to make new friends.

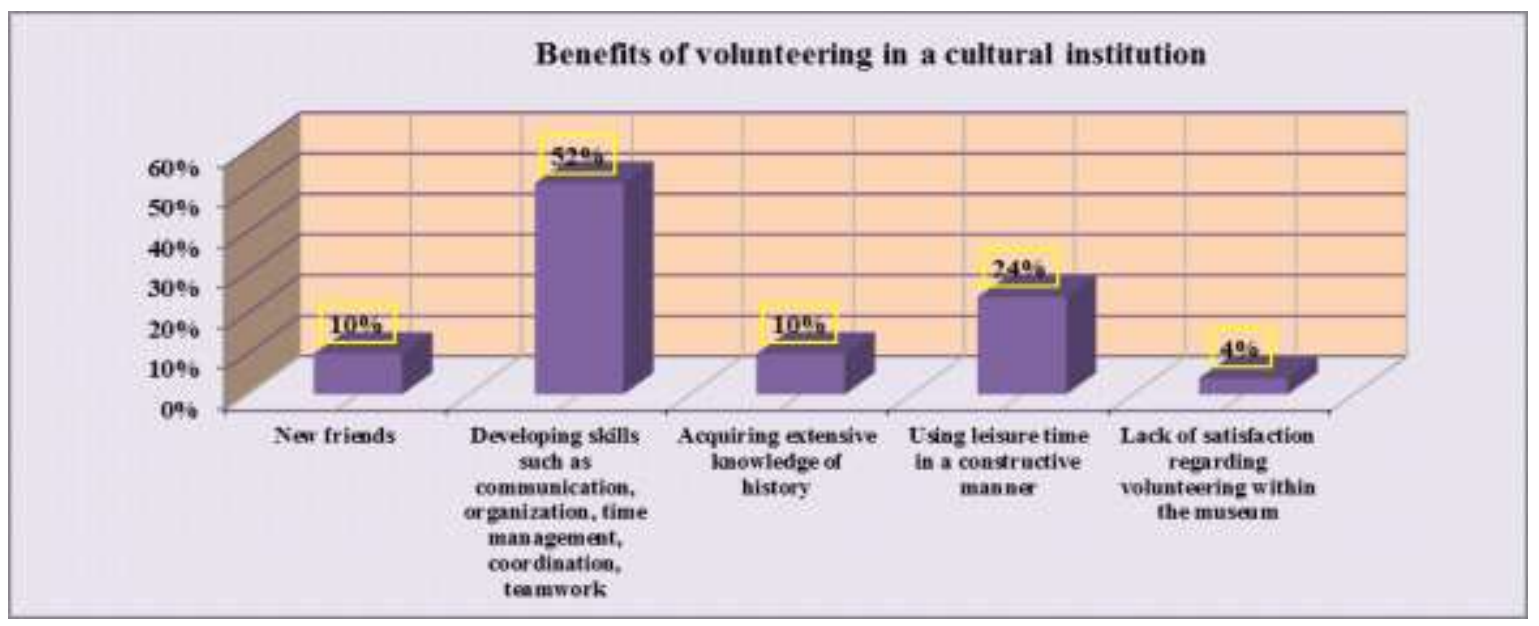

Figure 11. Benefits of volunteering in a cultural institution Source: Author, 2020 
Figure 12 shows the benefits felt by volunteers involved in the activities of the National Museum of Romanian History. The Likert Scale was used for each of the four response options (experience; interaction with specialists in the field; possibility to develop the oral speech; acquiring knowledge that you cannot get on your own). The respondents' opinions are different. However, most of them have a positive impression because they ticked "to a very great extent" and "to a great extent".

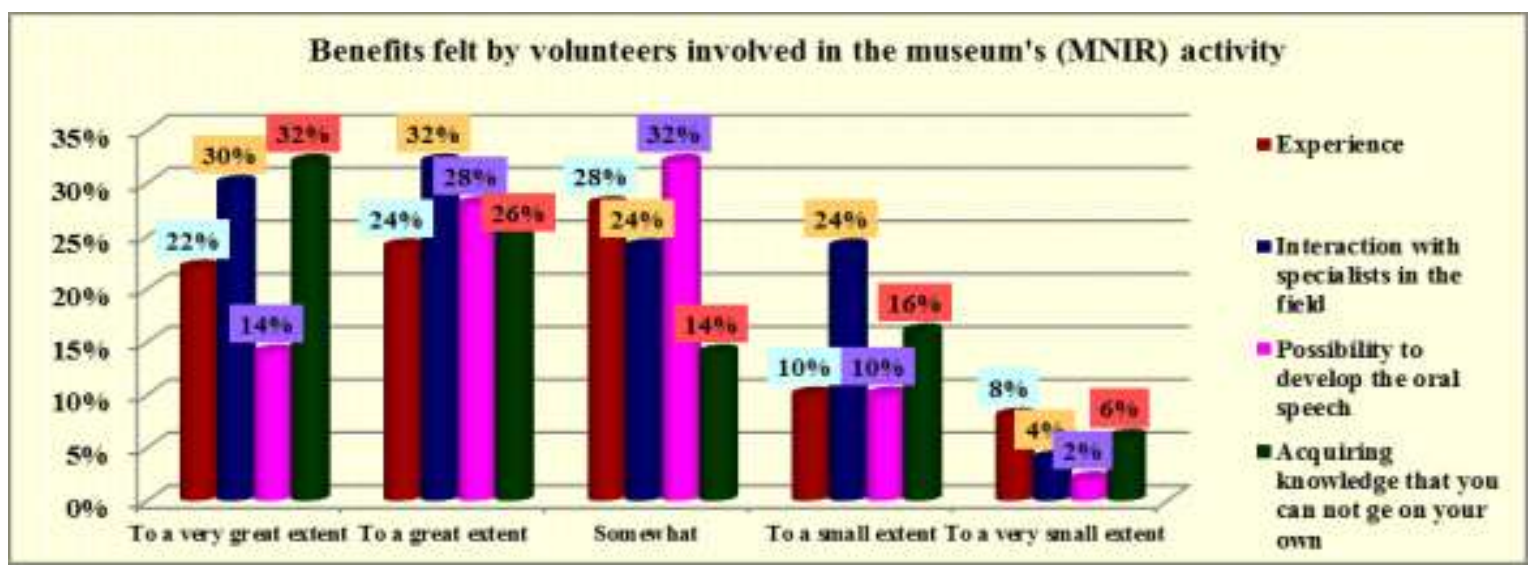

Figure 12. Benefits felt by volunteers involved in the museum's (MNIR) activity Source: Author, 2020

Question 13 refers to the respondents' level of satisfaction regarding the volunteering program within the museum. $62 \%$ of them ticked "Extremely satisfied" while the remaining $38 \%$ ticked "Satisfied", which can also hide small disappointments. As noted in Figure 13, none of the respondents had a negative opinion about the program.

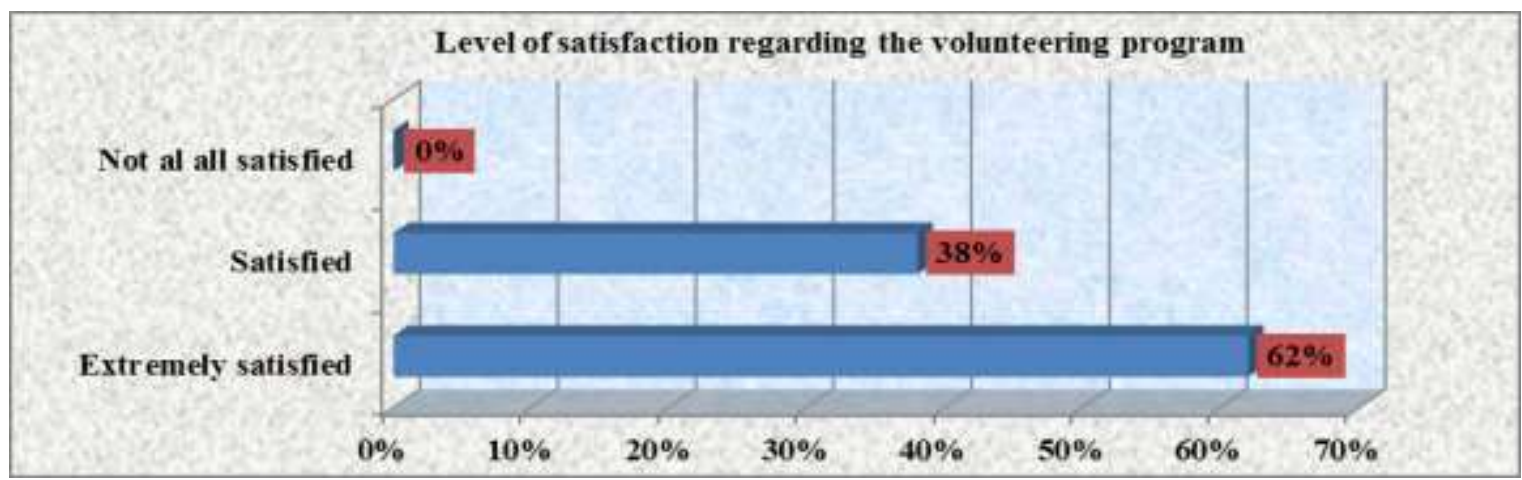

Figure 13. Level of satisfaction regarding the volunteering program Source: Author, 2020

As shown in figure 14, 92\% of the respondents consider volunteering activities as a constructive way of spending leisure. For the other $8 \%$ volunteering in museums is not useful. In fact, it is possible that the $8 \%$ of the respondents should be newer volunteers who did not have the opportunity to enjoy the advantages of working in the museum. 


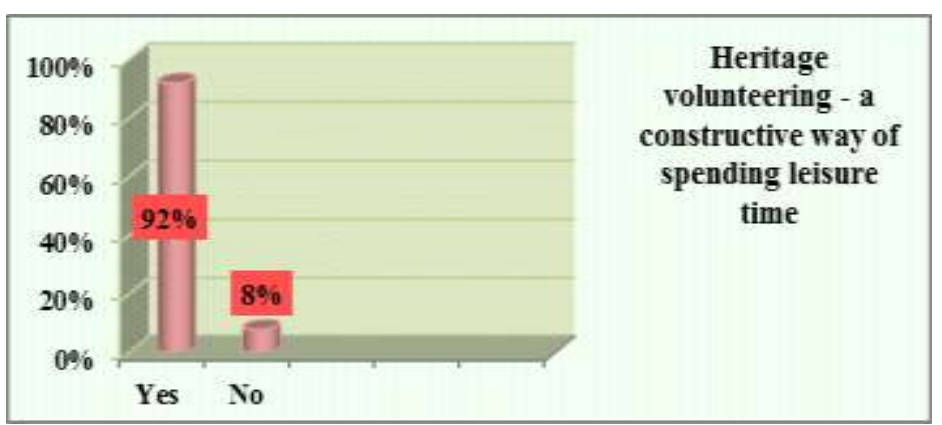

Figure 14. Heritage volunteering - a constructive way of spending leisure time Source: Author, 2020

Question 15 (Figure 15) refers to the role of heritage volunteering in professional development. According to $92 \%$ of the participants in this study, volunteering in the museum is important for their development, while for the others $8 \%$ is not useful in their future career. The great number of positive answers can be associated to the fact that half of the museum's volunteers come from the Faculty of History and will probably embrace a career in this field. Moreover, it is possible that some of the respondents may have become aware that their skills could help them regardless of the nature of the work performed.

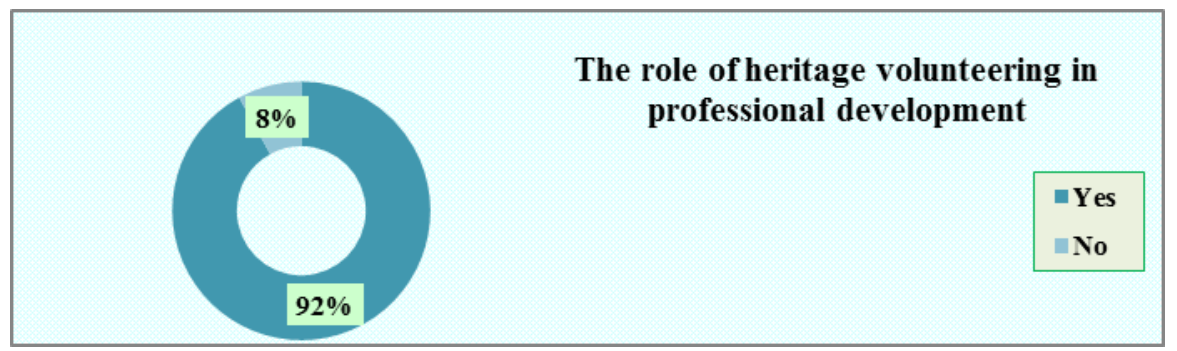

Figure 15. The role of heritage volunteering in professional development Source: Author, 2020

Analyzing figure 16 , one can state that $70 \%$ of the respondents attended informal training courses while $16 \%$ formal training courses and the remaining 14\% did not participate in training courses. Depending on the skills required, volunteers undergo a training period, before the volunteering start. For example, during 2014-2018 the volunteers benefited from a training period of about 3 weeks, which justifies the high percentage of those attending formal (14\%) and informal training courses (70\%).

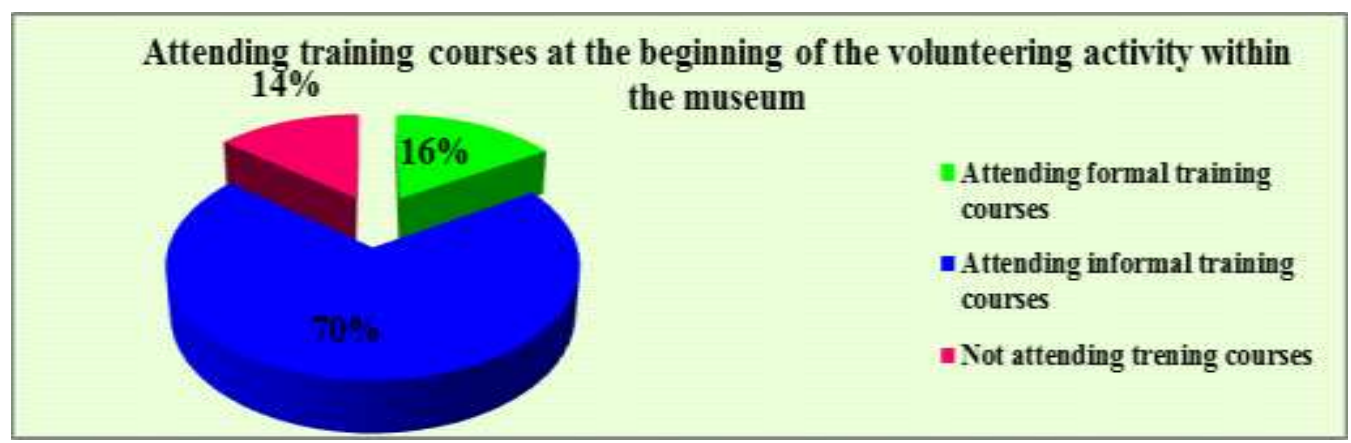

Figure 16. Attending training courses at the beginning of the volunteering activity within the museum Source: Author, 2020 
As regards the small number of those not attending training courses, they are probably new volunteers, involved in the museum's activities for several months. Taking into account the recent involvement period, it is possible that the training courses should not have been held because the minimum number of participants would not have been sufficient.

Furthermore, it is important to mention that informal courses are predominant in the National Museum of Romanian History, as they do not involve high financial costs and could be held during the daily work activities of 8 hours. Moreover, the museum focuses on learning at the "workplace" and gaining knowledge by involving in activities, this practice being in accordance with Groninger's (2011) statement mentioned above in the section Theoretical background.

The last 4 questions of the questionnaire are open-ended.

Question 17 aims to find out the opinion of volunteers' friends about their activity within the museum. Out of 50 respondents only 48 answered. Thus, 42 participants attending this study are supported by friends who admire them for what they do and are surprised that they find time for such constructive activities. Moreover, some of them added that they convinced a few friends to become volunteers within this institution. As for the other six volunteers, their friends are either indifferent or do not support them because they consider that the museum's activities are not related to their field of study. The answers relevant to this question are mentioned below:

"It depends on friends. Most of them consider that volunteer work is beneficial to their personally development".

"It's a positive one, because I convinced them to visit the museum or join the volunteer program".

"They are reluctant because the field of activity of the museum does not correspond to the field studied at the university."

Question 18 focuses on the change that heritage volunteering has brought to volunteers' lives. Out of 50 respondents only 45 answered. According to 5 respondents, volunteering in the museum did not bring changes in their life while for the other 40 the following items were important: broadening the knowledge sphere, personal development (overcoming the emotions of public speaking, increasing the desire to get involved, better organization of time), working with students, building friendships, desire to work in the field in the future. Some conclusive answers are provided below:

"I gained experience; I learned to work in a team."

"I became much more patient and responsible; I had the opportunity to accumulate new knowledge."

"For several years, the museum has become my life from an academic, professional, social and cultural perspective."

"For me, the short period within the museum brought a lot of beautiful people (as regards the character), interesting experiences, collaborations and the opportunity to live in other times."

Question 19 refers to the respondents' proposals regarding the improvement of the volunteering activity in the heritage sector. Out of 50 participants in the study, only 40 answered. Most of the responses focused on better promoting the volunteering program, signing partnerships with educational institutions, openness from the museum management, organizing volunteering programs in each museum, state support and providing a coherent infrastructure to support work with volunteers (programs, courses, summer schools, workshops). Some suggestions made by the respondents are presented below:

"First, the museums should have a promotion policy in order to attract volunteers. In our country the museums are neglected by our own authorities and their management".

„Partnerships with educational institutions; better training of volunteers by the museum staff, better promotion of volunteer programs".

"A diversification of activities would be useful, so that volunteers can figure out what suits them". As regards question 20, 46 respondents out of 50 provided answers about what causes them 
satisfaction when involving in the museum activity. The respondents mentioned the interaction both with the specialists and with the visitors, the experience gained, the accumulation of certain knowledge in the field and the help provided to the Romanian culture. Some of the answers are shown below:

"The interaction with people working there and the experience which could be included in $C V . "$

"The knowledge and information you can share with the others in various forms." This answer also highlights the educational mission that volunteers have within the museum.

"The helping hand you could give to the Romanian culture".

The responses to the questionnaire validated all the three hypotheses.

Hypothesis 1 "Volunteers within the museum are strongly motivated enjoying non-financial benefits" was validated by the answers to questions no. 10, 11 and 12. According to the respondents, their involvement in the museum's activities is based on social motivations (interaction with people interested in history and heritage, with specialists in the field), development (improving skills and gaining new skills, developing communication skills and public speaking skills), cognitive (desire to accumulate knowledge, to acquire experience in the field), affective (building relationships).

Hypothesis 2 "At least $50 \%$ of the respondents learned about the volunteering program from the university where they study" was validated by the answers to questions no. 4 and 7 . The answers to question 4 show the faculties where the museum's volunteers study or have studied. As regards question 7, half of the respondents learned about the volunteering program within the museum from the educational institution they attend. The answers to these questions support the assertion of Howlett et al. (2005) mentioned above in the section Theoretical background about volunteers' recruitment by cultural institutions.

Hypothesis 3 "Volunteers' involvement in the activities of the museum is closely related to their professional development" was validated by the answers to questions no. 10 and 15 . According to question 10, the respondents consider that cultural volunteering could help them gain experience in the field, develop professionally while employment opportunities increase considerably. Regarding question $15,92 \%$ of the museum's volunteers agreed that heritage volunteering has an important role in their professional development. Moreover, the latter could represent a very important reason for the social individuals' involvement in volunteering in cultural institutions.

\section{RESEARCH LIMITATIONS}

The present research has several limitations generated primarily by the rigid relationship between the researcher and the respondents caused by the administration of a formalized questionnaire not allowing the communication with the respondents. Most of the questions are closed-ended each of which have variants of answer, which has the advantage of rapid processing the results.

Another limitation refers to the investigation technique (questionnaire), which consists of general questions not allowing the respondent's examination in all his/her complexity, but only as a whole, the respondents being limited by the proposed variants of answer. Moreover, the population was limited to volunteers from the National Museum of Romanian History, individuals aged between 18 and 30 years.

Another disturbing element is the seriousness of the respondents in completing the questionnaire. Some of them did not answer all the open-ended questions while others provided unrealistic, superficial and unreliable answers which were not related to the subject under study. The researcher could not understand the reasons why some volunteers provided such answers. 


\section{CONCLUSIONS}

This research aiming to analyze the role of heritage volunteering in young people's development highlights some aspects and trends regarding volunteering in a museum in Bucharest.

Volunteers involved in the museum's activities are or have been students of various faculties from Bucharest's universities. They are oriented towards knowledge accumulation, and are characterized by an increased need to learn new things related to history and other fields. They are involved in many activities within the museum such as guided tours, educational workshops, processing of ceramic material, arranging exhibitions. Moreover, their answers show that they are intrinsically, cognitively and emotionally motivated because they are interested in history, knowledge, socialization and acquisition of certain skills. Furthermore, volunteering in this sector also has a vital contribution to students' education and training.

Heritage volunteering makes an important contribution to the community. If the volunteers were not involved in the museum's activities, guided tours and educational workshops could not be done so often because the staff would not have time to deal with them. Volunteering within the museum leads to costs savings, makes it possible to carry out activities that could not have been successfully completed under normal conditions, increases diversity and contributes to bringing a new breath, as students are always enthusiastic and full of ideas for improving their work.

The purpose of this paper was also to highlight the importance of a type of volunteering that could help its practitioners to spend their leisure time in a constructive way and to develop personally and professionally. In a society where people are gradually becoming the slaves of technology, heritage volunteering can be an option through which young generations can prevent the so-called "digital dementia" (Spitzer, 2012), thus managing to become rich from cultural and professional perspective and to avoid the sharp decline of cognitive abilities caused by the excessive use of technology.

\section{REFERENCES}

Ardelean, F. A. (2009). „Cum ne promovăm-despre infrastructura sectorului cultural”, Retrieved online August 3, 2019 from http://dilemaveche.ro/sectiune/din-polulplus/articol/cum-ne-promovam-despre-infrastructura-sectorului-cultural\#.

Babbie, E. (1992). The Practice of Social Research. $6^{\text {th }}$ edition. Belmont: Wadsworth Company.

Babbie, E. (2013). The Practice of Social Research. 13 $3^{\text {th }}$ edition. Canada: Wadsworth, Cengage Learning.

Balogh, N. \& Balogh, M. (2013). Managementul organizațiilor neguvernamentale și nonprofit. Cluj-Napoca: Tritonic Books.

Catlin-Legutko, C. \& Klingler, S. (2012). The small museum toolkit: Leadership, mission, and governance. Landham, Maryland: Rowman Altamira.

Chelcea, S. (1975). Chestionarul în investigația sociologică. București: Editura Științifică și Enciclopedică.

Chelcea, S. (2007). Metodologia cercetării sociologice - Metode cantitative și calitative. București: Editura Economică.

Chen, X. (2014). Understanding volunteers in cultural tourism organisations in new Zealand: exploring demographics and motivational factors. Retrieved August 2, 2019, from https://core.ac.uk/download/pdf/56364607.pdf. 
Dake, J. (2014). Dennos Museum Center Docent Handbook 2018-2019. Retrieved August 7, 2019 from http://www.dennosmuseum.org/education/docent/Forms/ docenthandbook.pdf.

Debo, T. A. (2013). Volunteers in Museums: Are Small Museums Utilizing Volunteer Management Policies? Retrieved July 19, 2019 from https://pdfs.semanticscholar.org/ 3e2e/10facd5dcaeb80fa44238be83df465ea2cf4.pdf.

Dickens, B. \& Blomberg, R. (1988). Evaluating volunteer experience of women re-entering the work force. Personnel Journal. 67(12), 94-99.

Edwards, D. (2005). It's mostly about me: reasons why volunteers contribute their time to museums and art museums. Tourism Review International, 9, 21-31.

Edwards, D. \& Graham, M. (2006). Museum volunteers: A discussion of challenges facing managers in the cultural and heritage sectors. Australian Journal of Volunteering, 11, $19-27$.

Gaskin, K. (2003). A choice blend - What volunteers want from organization and management. Retrieved July 24, 2019, from https://www.bl.uk/britishlibrary/ /media/ $\mathrm{bl} / \mathrm{global} /$ social-welfare/pdfs/non-secure/a/c/h/a-choice-blend-what-volunteers-wantfrom-organisation-and-management-18.pdf.

Groninger, K. (2011). Volunteering and professionalisation in UK museums. St Andrews Journal of Art History and Museum Studies, 15, 23-29.

Grossman, J. B. \& Furano, K. (1999). Making the Most of Volunteers. Law and Contemporary Problems. 62, 199-218, Retrieved June 11, 2019, from https://scholarship.law.duke.edu/lcp/vol62/iss4/10/.

Hall, E. (1995). Investing in volunteers: A guide to effective volunteer management. Preservation Information Series. Washington, D.C.: National Trust for Historic Preservation.

Handy, F., Cnaan, R. A., Brudney, J. L., Ascoli, U., Meijs, L. C. M. P. \& Ranade, S. (2000). 'Public perception of "who is a volunteer": an examination of the net-cost approach from a cross-cultural perspective', Voluntas, 11, 45-65, Retrieved June 25, 2019, from https://link.springer.com/article/10.1023/A:1008903032393.

Haski-Leventhal, D., Meijs, L. C. P. M. \& Hustinx, L. (2009). The Third-party Model: Enhancing Volunteering through Governments, Corporations and Educational Institutes. Journal of Social Policy. 39(1), 139-158, Retrieved July 17, 2019, from https://www.cambridge.org/ core/journals/journal-of-social-policy/article/thirdpartymodel-enhancing-volunteering-through-governments-corporations-and-educationalinstitutes/D667CCAB27D230B73B4 D4E3BD89BF6DD.

Henderson, K. A. (1981). Motivations and perceptions of volunteerism as a leisure activity. Journal of leisure research. 13(3), 208-218, Retrieved July 10, 2019, from https://www.tandfonline.com/doi/abs/10.1080/00222216.1981.11969484.

Hirzy, E. C. (2007) Transforming Museum Volunteering: A Practical Guide for Engaging 21st Century Volunteers. Washington, D.C.: American Association for Museum Volunteers.

Holmes, K. J. (1999). Changing Times: Volunteering in the Heritage Sector 1984-1998, Voluntary Action, 1(2), 21-35.

Holmes, K. J. (2002). Volunteer and Visitor Interaction in the UK Heritage Sector: motives and benefits. Retrieved July 29, 2019 from https://core.ac.uk/download/pdf/8780234.pdf.

Holmes, K. J. (2003). Volunteers in the heritage sector: a neglected audience? International 
Journal of Heritage Studies, 9(4), 341-355.

Holmes, K. J. (2005). Volunteering in the UK Museums Sector: The Case of Aspiring Museum Professionals. Retrieved August 2, 2019, from http://neumann.hec.ca/aimac 2005/PDF_Text/Holmes_Kirsten.pdf.

Holmes, K. \& Edwards D. (n.d.). Volunteers as hosts and guests in museums. Retrieved August 5, 2019, from https://pdfs.semanticscholar.org/008f/4951596d6ee7396400634d7 eff827c8387ea.pdf.

Hooper-Greenhill, E. \& Chadwick, A. (1985). Volunteers in museums and galleries: a dicussion of some of the issues. Museums Journal, 84(4), 177-178.

Howlett, S., Machin, J. \& Malmersjo, G. (2005). Volunteering in Museums, Libraries and Archives. Retrieved August 4, 2019, from http://www.volunteerspirit.org/files/volunteer _survey_2006_9500.pdf.

Hustinx, L., Cnaan, R. A. \& Handy, F. (2010) Navigating Theories of Volunteering: A Hybrid Map for a Complex Phenomenon. Journal for the Theory of social Behaviour, 10(4), 410-434, Retrieved July 3, 2019, from https://onlinelibrary.wiley.com/ doi/abs/10.1111/j.1468-5914.2010.00439.x.

International Association for Volunteer Effort. (2001). The Universal Declaration on Volunteering. Retrieved June 18, 2019, from https://www.iave.org/advocacy/theuniversal-declaration-on-volunteering/.

Jupp, V. (2010). Dicţionar al metodelor de cercetare socială. Iaşi: Editura Polirom.

Kelemen, M., Mangan, A. \& Moffat S. (2017). More than a 'little act of kindness'? Towards a typology of volunteering as unpaid work. Retrieved August 1, 2019, from http://eprints.keele.ac.uk/2866/1/Volunteering_as_unpaid_work_final.pdf.

Kelly, L., Savage, G., Landman, P. \& Tonkin S. (2002). Energised, engaged, everywhere: Older Australians and museums. Sydney and Canberra: Australian Museum and The National Museum of Australia.

Kotler, N. \& Kotler, P. (2001). Can museums be all things to all people?: Missions, goals, and marketing's role. Museum Management and Curatorship, 18, 271-287, Retrieved July 24, 2019, from https://www.tandfonline.com/doi/abs/10.1080/09647770000301803.

Kuyper, J., Hirzy, E. \& Huftalen, K. (1993). Volunteer program administration: A handbook for museums and other cultural institutions. New York: American Council for the Arts.

Lord, G.D. \& Lord, B. (2009). The manual of museum management. 2nd ed. Lanham, MD: AltaMira Press.

Mattingly, J. (1984). Volunteers in Museums and Galleries: The Report of a Survey into the Work of Volunteers in Museums and Galleries in the United Kingdom. Berkhamstead, Hertfordshire: The Volunteer Centre Uk.

McLean, F. (1997). Marketing the Museum. UK: Psychology Press.

Millar, S. (1991). Volunteers in museums and heritage organisations: policy, planning and management. London, UK: HMSO.

MNIR: Muzeul Naţional de Istorie a României. (2014). Regulament de organizare și funcționare al Muzeului Naţional de Istorie a României. Retrieved August 2, 2019, from http://mnir.ro/file/PDF/OMC_nr_2617_12.09.2014_ROF_MNIR.pdf.

MNIR: Muzeul Naţional de Istorie a României. (2017). Proiect de Management pentru Muzeul Naţional de Istorie a României 2017-2021. Retrieved July 8, 2019 from 
http://mnir.ro/wp-content/uploads/2017/01/PROIECT_MANAGEMENT_MUZEUL-_ NATIONAL_DE_ISTORIE_A_ROMANIEI.pdfMUZEUL_NATIONAL_DE_ISTORIE _A_ROMANIEI.pdf.

Ohlandt, N. L. (2013). Creating a Greater Connection: Volunteer Training in Seattle-area Museums. Retrieved August 4, 2019 from https://pdfs.semanticscholar.org/9385/ 7f97d7801ab02bce83840fa7fd595a45b5e9.pdf.

Păceșilă, M. (2017). Corporate volunteering: trends, benefits and challenges. Current situation in Romania. Theoretical and Empirical Researches in Urban Management. 12(2), 19-29, Retrieved July 19, 2019, from http://www.um.ase.ro/no122/2.pdf.

Popescu, I. \& Corboș, R. (2013). Competitivitatea organizațiilor culturale în contextual dezvoltării urbane. București: Editura ASE.

Profiroiu, A. G. \& Păceșilă, M. (2017). Volunteering: a route to the students professional development. Administraţie si Management Public, 29, 91-97.

Putnam, R. D. (2000). Bowling alone: The collapse and revival of American community. New York: Simon and Schuster.

Rodriguez, K. J. \& Gutierrez, D. V. (2010). Voluntarism and Social Responsabilty in Young Students of Higher Education in the Province of Concepcion, Chile/ Voluntariado y responsabilidad social en jóvenes estudiantes de educación superior de la provincia de Concepción, Chile. Trayectorias, 31, 137-152.

Smith, J. D. (1996). Should Volunteers be Managed? In Billis D. and Harris M (Eds). Voluntary Agencies. Challenges of Organisation and Management. (pp. 187-199). London: Macmillan.

Smith, K. A. (1999). The management of volunteers at heritage attractions: literary heritage properties in the UK. Doctoral dissertation. Nottingham: Nottingham Trent University.

Spitzer, M. (2012). Digitale Demenz: Wie wir uns und unsere Kinder um den Verstand bringen. München: Droemer HC.

Whittaker, J., McLennan, B. \& Handmer, J. (2015) A review of informal volunteerism in emergencies and disasters: Definition, opportunities and challenges, International Journal of Disaster Risk Reduction, 13, 358-368, Retrieved July 27, 2019, from https://www.sciencedirect.com/science/article/pii/S2212420915300388.

Wuthnow, R. (1998). Loose connections: Joining together in America's fragmented communities. Cambridge, Massachusetts: Harvard University Press.

Wymer, W., Riecken, G. \& Yavas, U. (1997). Determinants of volunteerism: A crossdisciplinary review and research agenda. Journal of Nonprofit \& Public Sector Marketing, 4 (4), 3-26, Retrieved July 26, 2019, from https://www.tandfonline.com/doi/ abs/10.1300/J054v04n04_02.

Wymer, W. (2011). The Implications of Sex Differences on Volunteer Preferences. Voluntas: International Journal of Voluntary and Nonprofit Organizations. 22(4), 831-851, Retrieved June 21, 2008, from https://link.springer.com/article/10.1007/s11266-0109174-0.

Yang, J. (2015). The Art and Culture Companions: Art Museum Volunteering as Serious Leisure in Finland. International Journal of the Inclusive Museum. 7(3/4), 9-20. 